While Stan may have concluded early on that he was not by nature a litigator, he was nevertheless a lawyer who made good use of his training and law degree. He was a member of the United States Supreme Court Bar, for eight years chairman of the Ombudsman Committee of the American Bar Association's Administrative Law Section, and for 40 years a member of the Santa Barbara County Bar Association. While teaching he was a mentor and inspiration to many local attorneys, and after retirement was lauded by the local bar association for his pro bono work with indigent felony defendants. In 2002 he received the Santa Barbara County Bar Association's Richar Abbe Humanitarian Award "for his lifelong devotion to humanitarian service."

I first met Stan in 1964, in Washington, D.C., where he was completing his Congressional Fellowship year and I was returning from my first year at UCSB to complete research on a project for the Brookings Institution. We arranged to meet for dinner, and then go to a baseball game at what later became RFK Stadium. I brought a friend from Brookings, and when the three of us got to the stadium we found two empty seats at one end of our row, and one at the other end. Stan stood in front of the row and asked if everyone could move over one seat, so that the three of us could sit together. It was a reasonable request, gently tendered, and they did. That was the Stan Anderson I came to know for 45 years, my model citizen. Were it not for problems of scale that require collective action, a libertarian community composed of Stan Andersons might actually work. Stan is survived by his wife Mary, his son and daughter-inlaw Stefan and Chi, his brother Bob, and an extended family beyond counting.

John E. Moore Professor Emeritus University of California, Santa Barbara

\section{ALEX DRAGNICH}

doi:10.1017/S1049096509990886

Following a period of declining health, Alex Dragnich died of pneumonia on August 10, 2009, at the age of 97. His mind remained sharp and his pen vigorous until almost his death.

He was especially notable for having, in effect, two careers. The first: teacher and scholar. The second, after retiring: scholar and commentator on public affairs. Each of these careers spanned 30 years. He published more after he had retired than he had before retiring, six of his eleven books, for example. During his second career, he not only wrote books, but also authored journal and op-ed articles, as well as letters to the editor. He participated frequently in Washington, D.C., policy seminars and appeared on TV programs.

Dragnich's life was the classic American success story. He was the son of Serbian immigrants. Difficult as it is to believe, he really did grow up in a log cabin in the Pacific Northwest. He didn't start school until he was nine, following a visit from the truant officer, who explained to his parents about compulsory education. $\mathrm{He}$ eventually graduated Phi Beta Kappa from the University of Washington and earned a Ph.D. at the University of California, Berkeley.

DuringWorldWar II he served as a social science analyst for the Department of Justice and the Office of Strategic Services. After teaching at Case Western Reserve, he became Cultural Attache and Public Affairs Officer at the American Embassy in Belgrade, Yugoslavia, from 1947 to 1950. This post shaped his entire career.

The chancellor of Vanderbilt University, Harvie Branscombe, on a mission for the U.S. government, met Dragnich in Belgrade. He was so impressed that he offered him an appointment as associate professor, should he decide to leave government service. Two years later, Dragnich went to Vanderbilt, teaching there from 1950 to 1978.

Branscombe sought advice from Dragnich on recruiting a chair who could build a reputable political science department. Avery Leiserson was brought from the University of Chicago to accomplish this mission. During more than a decade as chair, Leiserson worked closely with Dragnich. When he retired as chair, Dragnich took over from 1964 to 1969 . The two of them built a department of note. In 1970 Dragnich received the Thomas Jefferson Award for distinguished service to Vanderbilt.

This was just one of many awards and honors. He was Chester Nimitz Professor at the U.S. Naval War College in 1959-6o, a research fellow at the Hoover Institution in 1978-81, and a distinguished lecturer at Washington and Lee University in 1982. In 2002 he received the Yugoslav Star, First Class, medal from the presi- dent of Yugoslavia in recognition of his efforts to enhance Serbia's image in the United States. He served as president of the Southern Political Science Association and as vice president of the American Political Science Association.

He did not court controversy, but wasn't afraid to go against the flow. His first book, Tito's Promise Land: Yugoslavia (1954), was unfashionable. Many students of international affairs had come to view Tito as leader of a "third world" grouping, bridging the cold war chasm between the United States and the Soviet Union. Dragnich, however, understood fully the oppressive nature of the Tito regime, having himself lived under surveillance during his years in Yugoslavia. He published his final book, Serbia Through the Ages (2004) at age 92.

His comparative politics textbook, Major European Governments, was widely adopted, going through nine editions over more than a third of a century. His considerateness is attested to by the harmonious relations with Jorgen Rasmussen and Joel Moses, who became coauthors in the later editions.

In his personal relations he was mild and unassuming, leading by example, rather than by command. Nonetheless, he was fervent in support of his basic values.

He was predeceased by his wife and one son and survived by a son, a daughter, and three grandchildren. He took great pleasure in his family. Clichés, by definition, are overused. They sometimes provide, however, the most apt assessment. Alex Dragnich was, indeed, a gentleman of the old school.

Jorgen Rasmussen Distinguished Professor Emeritus Iowa State University

\section{ROBERT W. JACKMAN}

doi:10.1017/S1049096509990898

Robert W. Jackman, Distinguished Professor of Political Science at the University of California, Davis, died peacefully in San Francisco on October 8, 2009, after a long, courageous struggle with pancreatic cancer.

Bob was born on October 31, 1946, in Oamaru, New Zealand, the first-born child of two school teachers, David and Helen Jackman. His father was a veteran of the North African campaign in WWII, and he and his new wife sought a quiet life teaching in rural Maori communities. Bob's 